\title{
PERAN SUBSEKTOR PETERNAKAN TERHADAP SEKTOR PERTANIAN PADA PEREKONOMIAN WILAYAH PROVINSI LAMPUNG
}

\section{THE ROLE OF THE LIVESTOCK SUBSECTOR ON THE AGRICULTURE SECTOR IN THE ECONOMY OF THE LAMPUNG PROVINCE}

\author{
Rino Hadiwijaya Puradireja ${ }^{* 1}$, Achmad Firman ${ }^{2}$ \\ ${ }^{1}$ Program Pascasarjana Fakultas Peternakan, Universitas Padjadjaran \\ Jl. Raya Bandung Sumedang Km 21, Jatinangor Sumedang \\ ${ }^{2}$ Departemen Sosial Ekonomi Pembangunan Peternakan, Fakultas Peternakan, \\ Universitas Padjadjaran \\ Jl. Raya Bandung Sumedang Km 21, Jatinangor Sumedang \\ *Email: rino14001@mail.unpad.ac.id \\ (Diterima 30-03-2021; Disetujui 03-06-2021)
}

\begin{abstract}
ABSTRAK
Penelitian ini bertujuan untuk menentukan subsektor-subsektor unggulan pada sektor pertanian yang dapat dikembangkan di Provinsi Lampung yang. Penelitian ini menggunakan data sekunder yang diperoleh dari Badan Pusat Statistik Nasional dan Provinsi Lampung. Metode analisis yang digunakan dalam perhitungan ini terdiri dari Location Question (LQ), Shift Share (SS) dan Tipologi Klassen. Hasil penelitian ini menunjukkan bahwa subsektor tanaman pangan, peternakan, jasa pertanian dan perburuan, dan perikanan memiliki nilai LQ $>1$. kan merupakan subsektor pertanian yang berkontribusi besar pada PDRB Provinsi Lampung. Adapun yang memiliki nilai Shift Share (SS) positif adalah subsektor tanaman pangan, jasa pertanian dan perburuan, dan perikanan. Berdasarkan kedua analisis LQ dan SS dapat dihitung nilai Tipologi Klasen yang menunjukkan subsektor-subsektor pertanian yang memiliki unggulan adalah subsektor tanaman pangan, jasa pertanian dan perburuan, dan perikanan. Subsektor peternakan bukan sebagai unggulan dari Provinsi Lampung.
\end{abstract}

Kata Kunci : Location Question (LQ), Shift Share (SS), Subsektor Peternakan, dan Tipologi Klassen

\begin{abstract}
This study aims to determine the superior sub-sectors in the agricultural sector that can be developed in Lampung Province. This study uses secondary data obtained from the National Statistics Agency and the Province of Lampung. The analysis method used in this calculation consists of the Location Question (LQ), Shift Share (SS) and Klassen Typology. The results of this study indicate that the sub-sectors of food crops, livestock, agricultural services and hunting, and fisheries have a value of $L Q>1$. It is the agricultural sub-sector that contributes greatly to the PDRB of Lampung Province. Those with a positive Shift Share (SS) value are the sub-sector of food crops, agricultural services and hunting, and fisheries. Based on the two LQ and SS analyzes, the classification typology value can be calculated which shows that the superior agricultural subsectors are the food crops, agricultural and hunting services, and fisheries sub-sectors.
\end{abstract}

Keywords : Klassen Typology, Livestock subector, , Location Question, Shift Share 


\section{PENDAHALUAN}

Pembangunan wilayah bertujuan untuk meningkatkan daya saing wilayah, meningkatkan pertumbuhan ekonomi, mengurangi ketimpangan antar wilayah, serta memajukan kehidupan masyarakat. Pembangunan wilayah yang strategis dan berkualitas menjadi harapan setiap daerah di Indonesia. Pembangunan antar daerah dilakukan sesuai dengan potensinya masing-masing. Indikator keberhasilan dalam pembangunan wilayah yakni adanya pertumbuhan ekonomi, tingkat pengangguran yang semakin kecil dan pengurangan angka kemiskinan. Harapan terbesar dengan adanya pembangunan wilayah diharapkan daerah tersebut mampu bersaing dengan daerah lainnya atau dapat membangun ekonomi daerah secara mandiri.

Pembangunan didefinisikan sebagai rangkaian usaha mewujudkan pertumbuhan dan perubahan secara terencana dan sadar yang ditempuh oleh suatu Negara menuju arah yang lebih baik. Perencanaan pembangunan daerah pada dasarnya adalah bersifat multidisipliner karena cakupannya yang luas meliputi aspek geografi, ekonomi, sosial, budaya, politik, pemerintahan, dan fisik. Karena itu, penyusunan perencanaan pembangunan daerah memerlukan suatu tim perencana yang mempunyai beberapa keahlian dalam ilmu terkait seperti Planologi, Teknik, Ekonomi, Pertanian, Hukum, Pemerintahan, dan Sosial Budaya.

Pembangunan wilayah merupakan kunci untuk maju tidaknya sebuah daerah. Perencanaan pembangunan wilayah merupakan satu-satunya jalan yang terbuka untuk menaikkan pendapatan per kapita, mengurangi ketimpangan pendapatan dan meningkatkan kesempatan kerja (Jhingan, 2008). Pembangunan wilayah sebaiknya menggunakan dua pendekatan yakni pendekatan sektoral dan regional. Pendekatan sektoral adalah suatu pendekatan dimana seluruh kegiatan ekonomi didalam wilayah perencanaan dikelompokkan atas dasar sektor-sektor (contoh sektor jasa, pertanian, perkebunan, Peternakan, industri dan lainnya). Selanjutnya setiap sektor dianalisa lebih dalam untuk pengembangan lebih lanjut disesuaikan dengan potensi daerah. Sedangkan pendekatan regional merupakan pendekatan yang memandang wilayah sebagai kumpulan dari bagian-bagian wilayah yang lebih kecil dengan segenap potensi dan daya tariknya masingmasing. Konsentrasi dari pendekatan ini 
untuk merencanakan serta mensinergiskan seluruh komponen agar tercipta efektif dan efisien. Adapun pembangunan sektoral adalah pembangunan yang menitik beratkan terhadap apa yang perlu dikembangkan untuk mencapai tujuan pembangunan (Firman dan Obed, 2020). Perencanaan pembangunan sektoral adalah perencanaan yang dilakukan dengan pendekatan berdasarkan sektor. Yang dimaksud dengan sektor adalah kumpulan dari kegiatan-kegiatan atau program yang mempunyai persamaan ciri-ciri serta tujuannya. Pembagian menurut klasifikasi fungsional seperti sektor, maksudnya untuk mempermudah perhitungan-perhitungan dalam mencapai sasaran makro. Sektor-sektor ini kecuali mempunyai ciri-ciri yang berbeda satu sama lain, juga mempunyai daya dorong yang berbeda dalam mengantisipasi investasi yang dilakukan pada masingmasing sektor

Provinsi Lampung merupakan provinsi yang berdekatan dengan DKI Jakarta sebagai pusat ibu kota negara Indonesia. Wilayah DKI Jakarta memiliki potensi untuk dijadikan market. Wilayah Lampung memiliki potensi Sumber Daya Alam (SDA) yang sangat melimpah seperti SDA yang dapat diperbaharui seperti sektor pertanian, peternakan, perikanan dan perkebunan. Serta SDA yang tidak dapat diperbaharui seperti hasil tambang, minyak bumi dan gas alam. Sektor yang berkembang di Provinsi Lampung adalah sektor pertanian, peternakan, perburuan dan jasa pertanian. Selain sektor tersebut terdapat sektor Pertambangan dan penggalian, Industri pengolahan dan lainnya. Sektor pertanian memberikan kontribusi sebesar Rp 106.029.143,42 terhadap Pendapatan Domestik Regional Bruto (PDRB) Provinsi Lampung pada tahun 2020. Kontribusi tersebut menenpati urutan pertama dari seluruh sektor perekonomian di provinsi ini. Laju Pertumbuhan sektor pertanian, peternakan, perburuan dan jasa pertanian meemiliki laju pertumbuhan $0,81 \%$. Selain itu, sektor pertanian mampu menyerap tenaga kerjasebanyak 1.915.750 jiwa bekerja dari total 4.280.109 jiwa angkatan kerja di Provinsi Lampung (BPS Provinsi Lampung, 2021).

Salah satu subsektor yang berada di sektor pertanian adalah subsektor peternakan. Sub sektor ini berkontribusi terhadap PDRB Provinsi Lampung sebesar Rp 15.841.791,19 pada tahun 2020 (BPS, 2020). Sektor peternakan 


\section{PERAN SUBSEKTOR PETERNAKAN TERHADAP SEKTOR PERTANIAN \\ PADA PEREKONOMIAN WILAYAH PROVINSI LAMPUNG \\ Puradireja R.H., Firman A.}

sangat berkembang di Provinsi Lampung. Berdasarkan hasil data BPS Provinsi Lampung (2021), komoditas kambing merupakan hewan ternak terbesar populasinya yaitu sebanyak 1,45 juta ekor, sementara sapi potong di tahun 2019 sebanyak 819,6 ribu ekor. Populasi kambing terbanyak ada di Kabupaten Lampung selatan, sedangkan populasi sapi potong terbanyak ada di Kabupaten Lampung Tengah. Provinsi Lampung bisa dikatakan untuk produksi komoditas daging kuda bisa dikatakan tidak ada. Produksi daging terbesarnya adalah ternak sapi potong yang mencapai 13,68 ribu ton. Produksi daging unggas paling banyak diproduksi oleh ayam pedaging yang mencapai 42,49 ribu ton.

Berdasarkan data dari BPS Tahun 2019 yang dihimpun dari dinas peternakan. populasi sapi potong di Lampung Tengah sebanyak 363.500 ekor. Kemudian pada tahun 2020 mengalami peningkatan menjadi 370.770 ekor. Sedangkan untuk produksi daging sapi pada tahun 2018 di Lampung Tengah sebanyak $3.960 .056 \mathrm{Kg}$, dan tahun 2019 meningkat menjadi 3.980.361 Kg Peningkatan populasi sapi potong serta produksi daging sapi yang meningkat setiap tahun di Kabupaten Lampung Tengah dikarenakan pada kabupaten ini terdapat banyak perusahan sapi potong, diantaranya yaitu PT Indo Prima Beef, Great Giant Livestock, PT Karunia Alam Sentosa Abadi, PT Santori Agrindo, PT Sumber Cipta Kencana, PT Juang Jaya Abadi, dan lainnya.

Peran suatu sektor pada suatu wilayah dapat dianalisis oleh berbagai alat analisis wilayah, yaitu Analisis Location Quotient (LQ) adalah metode analisis yang digunakan untuk membantu menentukan kapasitas ekspor perekonomian di suatu wilayah dan derajat selfsufficiency suatu sektor. Analisis ini juga digunakan untuk mengetahui apakah sektor-sektor enkonomi tersebut termasuk kegiatan basis atau tidak sehingga dapat diketahui sektor apa saja yang masuk kategori sektor unggulan. Peritungan LQ digunakan untuk menunjukan perbandingan perbandingan tiap sektor ekonomi di tingkat regional dengan sektor ekonomi yang wilayahnya lebih tinggi satu tingkat diatasnya (Muta'ali, 2015). LQ adalah suatu alat pengembangan ekonomi yang lebih sederhana dengan segala kelebihan dan keterbatasannya. Teknik LQ merupakan salah satu pendekatan yang umum digunakan dalam model ekonomi basis sebagai langkah awal untuk memahami 
sektor kegiatan yang menjadi pemacu pertumbuhan. LQ mengukur konsentrasi relative atau derajat spesialisasi kegiatan ekonomi melalui pendekatan perbandingan. Nilai SS (Shift share) adalah menurut Muta'ali (2015) Persediaan pengaman sering juga disebut sebagai shift share adalah suatu persediaan yang dicadangkan sebagai pengaman dari kelangsungan proses produksi perusahaan untuk menghindari terjadinya kekurangan barang. Penentuan persediaan pengaman ini dipergunakan analisis statistik dengan melihat dan memperhitungkan penimpangan yang sudah terjadi antara perkiraan bahan baku dengan pemakaian sesungguhnya dapat diketahui besarnya standar dari penyimpangan tersebut. Tipologi Klasen adalah analisis tipologi ini dimanfaatkan untuk dapat mengetahui pola serta struktur pertumbuhan ekonomi dari masing-masing daerah.

Berdasarkan uraian diatas, tujuan dari penelitian ini adalah untuk melihat peran subsektor peternakan terhadap perekonomian wilayah provinsi Lampung yang dianalisis melalui nilai LQ, SS dan tipologi Klasen.

\section{METODE PENELITIAN}

Data yang digunakan dalam penelitian ini adalah data sekunder yang relevan dari berbagai sumber, khususnya berasal dari Badan Pusat Statistik Provinsi Lampung. Metode yang digunakan dalam penelitian ini adalah metode kuantitatif deskriptif. Metode kuantitatif bertujuan untuk menguji hipotesis yang telah ditetapkan yang digunakan untuk meneliti pada populasi maupun sampel tertentu, pengumpulan data dengan menggunakan instrument penelitian, serta analisis data yang bersifat kuantitatif atau statistik (Aulia dan Yulianti, 2019). Metode deskriptif digunakan untuk menggambarkan data hasil analisis tanpa bermaksud membuat kesimpulan yang berlaku umum

Teknik pengumpulan data studi ini dilakukan melalui situs Badan Pusat Statistik (2020) dan laporan Dinas Pertanian Provinsi Lampung (2020) serta data lainnya yang relevan dengan penelitian. Ada tiga analisis untuk menentukan komoditas unggulan ternak yaitu:

a. Analisis Location Quotient (LQ) digunakan untuk menentukan sektor basis dan non basis dalam perekonomian (Sapriadi dan Hasbullah. (2015). Menurut 
Guimaraes et al (2009), pada awalnya

LQ digunakan untuk kuantifikasi

konsentrasi industri di suatu wilayah.

Dalam perkembangannya, LQ

digunakan untuk memperkirakan

kekuatan pengaruh ekonomi wilayah dan kegiatan ekspor (ekonomi basis).

Analisis Location Quotient (LQ)

diformulasikan sebagai berikut

(Yuuhaa dan Cahyono, 2013):

$\mathrm{LQ}=\frac{V i / V t}{Y i / Y t}$

Keterangan :

Vi : nilai PDRB pada sektor i Provinsi

$\mathrm{Vt}$ : nilai PDRB seluruh sektor $\mathrm{t}$

Provinsi

Yi : nilai PDRB pada sektor $\mathrm{i}$

Nasional

Yt : nilai PDRB seluruh sektor $\mathrm{t}$

Nasional

Keterangan:

- Nilai LQ = 1; peternakan i sama dengan hasil pertanian lainnya

- Nilai LQ > 1; peternakan i menjadi komoditas unggul di Provinsi

Lampung

- Nilai LQ $<1$; peternakan i bukan komoditas unggulan di Provinsi Lampung.
Tabel 1. Penafsiran Nilai LQ

\begin{tabular}{|c|c|c|c|}
\hline \multirow[b]{2}{*}{$\begin{array}{c}\text { Nilai } \\
\text { LQ }\end{array}$} & \multicolumn{3}{|c|}{ Penafsiran } \\
\hline & $\begin{array}{c}\text { Sektor } \\
\text { Basis/ } \\
\text { Unggulan/ } \\
\text { Potensial }\end{array}$ & $\begin{array}{c}\text { Tingkat } \\
\text { Spesialisasi }\end{array}$ & $\begin{array}{l}\text { Pelayanan } \\
\text { Pasar }\end{array}$ \\
\hline $\begin{array}{l}\text { LQ } \\
=1\end{array}$ & $\begin{array}{c}\text { Sektor } \\
\text { Seimbang } \\
\text { dengan } \\
\text { wilayah } \\
\text { acuan }\end{array}$ & $\begin{array}{c}\text { Spesialisasi } \\
\text { sama dengan } \\
\text { wilayah } \\
\text { acuan }\end{array}$ & $\begin{array}{c}\text { Non } \\
\text { eksport, } \\
\text { hanya } \\
\text { mampu } \\
\text { melayani, } \\
\text { pasar } \\
\text { didalam } \\
\text { wilayah }\end{array}$ \\
\hline $\begin{array}{l}\mathrm{LQ} \\
>1\end{array}$ & $\begin{array}{c}\text { Sektor } \\
\text { basis dan } \\
\text { Unggulan }\end{array}$ & $\begin{array}{c}\text { Sektor } \\
\text { terspesalisasi }\end{array}$ & $\begin{array}{c}\text { Eksport } \\
\text { melayani } \\
\text { pasar } \\
\text { dalam dan } \\
\text { luar daerah }\end{array}$ \\
\hline $\begin{array}{l}\mathrm{LQ} \\
<1\end{array}$ & $\begin{array}{c}\text { Sektor } \\
\text { non basis } \\
\text { dan } \\
\text { unggulan, } \\
\text { tidak } \\
\text { potensial }\end{array}$ & $\begin{array}{l}\text { Sektor tidak } \\
\text { terspesialisasi }\end{array}$ & $\begin{array}{c}\text { Non } \\
\text { eksport, } \\
\text { belum } \\
\text { mampu } \\
\text { melayani, } \\
\text { pasar luar } \\
\text { daerah }\end{array}$ \\
\hline
\end{tabular}

Sumber: Muta'ali (2015)

b. Analisis Shift Share digunakan untuk mengurangi kelemahan-kelemahan dari LQ.

Analisis shift share banyak digunakan dalam menganalisis dampak dan menggambarkan tren pertumbuhan nasional, sektoral, dan regional (Gochsin 2014). Shift share dapat memperkirakan pertumbuhan regional dan menganalisis pengaruh dari inisiatif kebijakan serta mengembangkan perencanaan strategis untuk komunitas. Selain itu juga bisa untuk menguraikan pangsa pertumbuhan keseluruhan, pangsa komposisi diferensial, dan pangsa 
persaingan sektor (Rice dan Harton 2010).

Shift Share mengakui adanya perbedaan dan kesamaan antar wilayah. Formulasi Shift Share (SS) sebagai berikut (Muta'ali, 2015):

$\mathbf{S S}=\mathbf{K P N}+\mathrm{KPP}+\mathrm{KPPW}$

$\mathbf{S S}=(\mathbf{Y t} / \mathbf{Y o}-\mathbf{1})+(\mathbf{Y i t} / \mathbf{Y i o}-\mathbf{Y t} / \mathbf{Y o})$

$+($ yit/yio - Yit/Yio $)$

$\mathbf{S S}=[\mathbf{R a}-\mathbf{1}]+[\mathbf{R i}-\mathbf{R a}]+[\mathbf{r i}-\mathbf{R i}]$

Keterangan :

$\mathrm{Yt}=$ Indikator ekonomi wilayah nasional, akhir tahun analisis

Yo $=$ Indikator ekonomi wilayah nasional, awal tahun analisis

Yit $=$ Indikator ekonomi wilayah nasional sektor $\mathrm{i}$, akhir tahun analisis Yio $=$ Indikator ekonomi wilayah nasional sektor i, awal tahun analisis yit $=$ Indikator ekonomi wilayah lokal sektor i, akhir tahun analisis yio $=$ Indikator ekonomi wilayah lokal sektor i, awal tahun analisis Jika nilai yang didapat $(+)$ pada perhitungan pendapatan maka sektor tersebut termasuk dalam sektor kompetitif, namun jika yang di dapat adalah (-) sektor tersebut tidak kompetitif (Muta'ali, 2015).

c. Analisis Tipologi Klassen digunakan untuk mengidentifikasi sektor, subsektor, usaha, atau komoditi prioritas atau unggulan suatu daerah dan digunakan untuk mengetahui gambaran tentang pola dan struktur pertumbuhan sektor perekonomian suatu daerah. Tipologi Klassen sebagai alat analisis regional yang merupakan gabungan dari LQ dan SS yang disusun dalam suatu kuadran. Formulasi untuk tipologi klassen untuk potensi sektor perekonomian di suatu wilayah dapat dilihat pada gambar di bawah ini.

\begin{tabular}{|c|c|}
\hline Kuadran II & Kuadran I \\
Sektor (i) maju tapi & $\begin{array}{c}\text { Sektor (i) maju dan } \\
\text { tumbuh pesat }\end{array}$ \\
tertekan & (LQ $>1 ;$ SS + ) \\
\hline Kuadran IV & Kuadran III \\
Sektor (i) tertinggal & Sektor (i) berkembang \\
(LQ $<1 ;$ SS -$)$ & cepat \\
& $($ LQ $>1 ;$ SS -$)$ \\
\hline
\end{tabular}

Gambar 1. Analisis Tipologi Klasen (Firman dan Obed, 2020)

Menurut tipologi Klassen untuk kasifikasi produktivitas sektor ekonomi, sektor perekonomian wilayah terbagi menjadi empat klasifikasi, yaitu (Sjafrizal, 1997):

1. Sektor maju dan cepat tumbuh merupakan daerah atau kecamatan yang cepat maju dan cepat tumbuh (high growth and high income). Sektor ini merupakan sektor yang memiliki tingkat pertumbuhan ekonomi sektoral dan kontribusi sektor yang lebih tinggi dibandingkan dengan rata-rata lokal/regional. 
2. Sektor maju tapi tertekan merupakan daerah atau kecamatan yang berkembang cepat (high growth but low income). Sektor ini adalah sektor yang memiliki kontribusi sektor lebih tinggi tetapi tingkat pertumbuhan ekonomi sektoralnya lebih rendah dibandingkan dengan rata-rata lokal/regional

3. Sektor berkembang cepat merupakan daerah atau kecamatan maju tapi tertekan (low growth but high income). Sektor ini adalah sektor yang memiliki tingkat pertumbuhan sektoral tinggi, tetapi kontribusi sektor lebih rendah dibanding ratarata lokal/regional.

4. Sektor relatif tertinggal merupakan daerahatau kecamatan relatif tertinggal (low growth low income). Merupakan sektor yang memiliki tingkat pertumbuhan ekonomi sektoral dan kontribusi sektor yang lebih rendah dibandingkan dengan rata-rata lokal/regional.

\section{HASIL DAN PEMBAHASAN}

\section{Gambaran Sektor Perekonomian Provinsi Lampung}

Provinsi Lampung merupakan provinsi yang berdekatan dengan ibu kota negara yang hanya dibatasi oleh selat sunda. Salah satu sektor unggulan di
Provinsi Lampung dan menjadi idola bagi Kementrian Peranian adalah subsektor peternakan. Adapun kontribusi dari masing-masing subsektor pertanian dapat dilihat pada Gambar 1. Secara keseluruhan Provinsi Lampung mengalami peningkatan Produk Domestik Regional Bruto (PDRB) dari tahun 2015-2019. PDRB Provinsi Lampung mengalami kenaikan 1,051\% pada tahun 2016-2017, kemudian mengalami peningkatan sebesar 1,052\% pada tahun 2018-2019. Namun pada tahun 2020 mengalami penurunan pertambahan PDRB sebesar 0,069\%. Penurunan ini disebabkan adanya wabah penyakit nasional yakni pandemic Covid 19 yang mengganggu seluruh aspek kehidupan.

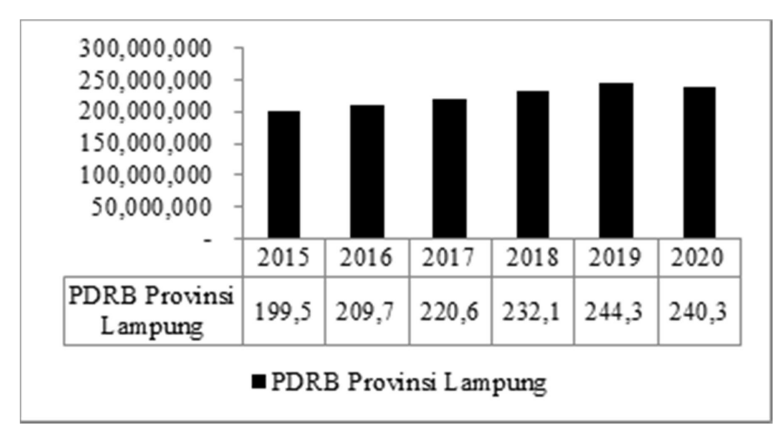

Gambar 2. Produk Domestik Regional Bruto (PDRB) Lampung (BPS, 2019)

\section{Kontribusi Subsektor-subsektor Pertanian terhadap PDRB Provinsi Lampung}

Sektor pertanian memiliki peranan penting karena berkontribusi besar terhadap PDRB Provinsi Lampung. 
Sektor pertanian merupakan sektor yang memiliki rata-rata indeks spesialisasi paling tinggi selama lima tahun terakhir, yaitu sebesar 0,35. Sektor ini perlu mendapat perhatian lebih agar memberikan manfaat bagi kesejahteraan masyarakat. Hal ini sejalan dengan pendapat Indrawati (2019) bahwa sektorsektor ekonomi yang berpotensial hendaknya lebih dikembangkan lagi sehingga di masa-masa yang akan datang sektor-sektor ekonomi tersebut dapat diandalkan untuk kontribusi perekonomian. Peran sektor pertanian ini tidak terlepas dari kontribusi dari masingmasing subsektor-subsektor yang berada di sektor pertanian, yaitu subsektor tanaman pangan, holtikultura, perkebunan, peternakan, jasa pertanian dan perburuan, kehutanan, dan perikanan. Adapun kontribusi dari masing-masing subsektor pertanian dapat dilihat pada Tabel 2.

Berdasarkan Tabel 2, kontribusi subsektor tanaman pangan sebesar $11 \%$ dalam PDRB Provinsi Lampung disusul setelahnya yakni komoditas perkebunan dan peternakan. Dalam upaya pembangunan wilayah, masalah yang terpenting yang menjadi perhatian para ahli ekonomi dan perencanaan wilayah adalah menyangkut proses pertumbuhan ekonomi dan pemerataan pembangunan. Sektor pertanian berperan penting dalam pertumbuhan suatu wilayah (Sirojuzilam, 2007).

\begin{tabular}{lcc} 
Tabel 2. & $\begin{array}{c}\text { Kontribusi } \\
\text { Pertanian Tahun 2020 }\end{array}$ \\
\hline $\begin{array}{c}\text { Lapangan } \\
\text { Usaha Sektor } \\
\text { Pertanian }\end{array}$ & $\begin{array}{c}\text { Nilai Ekonomi } \\
\text { Berdasarkan } \\
\text { Harga Berlaku } \\
\text { (Rp Juta) }\end{array}$ & $\begin{array}{c}\text { Kontribusi } \\
\text { Subsektor } \\
\text { Pertanian } \\
\text { (\%) }\end{array}$ \\
\hline $\begin{array}{l}\text { a. Tanaman } \\
\text { Pangan } \\
\text { b. Tanaman }\end{array}$ & $39.159 .225,08$ & 11,04 \\
$\begin{array}{l}\text { Hortikultura } \\
\text { c. Tanaman }\end{array}$ & $5.197 .849,83$ & 1,47 \\
$\begin{array}{l}\text { Perkebunan } \\
\text { d. Peternakan } \\
\text { e. Jasa } \\
\text { Pertanian dan } \\
\text { Perburuan }\end{array}$ & $21.772 .708,87$ & 6,14 \\
$\begin{array}{l}15.841 .791,19 \\
\text { f. Kehutanan }\end{array}$ & $2.750 .566,23$ & 4,47 \\
$\begin{array}{l}\text { g. Perikanan } \\
\text { PDRB }\end{array}$ & $1.021 .017,50$ & 0,78 \\
$\begin{array}{l}\text { Provinsi } \\
\text { Lampung }\end{array}$ & $354.631 .688,11$ & 0,78 \\
\hline
\end{tabular}

\section{Penentuan Nilai Location Quotient (LQ) Subsebktor Peternakan di} Provinsi Lampung

Sektor basis suatu wilayah dapat dianalisis dengan teknik Location Quotient (LQ) yang digunakan untuk mengetahui seberapa besar tingkat spesialisasi sektor basis atau sektor unggulan (leading sectors). Menurut Widjaya (2012), analisis ini dapat menggunakan variabel tenaga kerja atau Produk Domestik Regional Bruto (PDRB) suatu wilayah sebagai indikator pertumbuhan wilayah. Apablia nilai LQ bernilai lebih dari 1 (satu) 


\section{PERAN SUBSEKTOR PETERNAKAN TERHADAP SEKTOR PERTANIAN \\ PADA PEREKONOMIAN WILAYAH PROVINSI LAMPUNG \\ Puradireja R.H., Firman A.}

menunjukkan sektor tersebut dinilai unggul, sedangkan jika LQ bernilai bernilai kurang dari 1 (satu) menunjukkan sektor tersebut bukan sebagai sektor unggulan. Adapun hasil analisis subsektor-subsektor pertanian di Provinsi Lampung dapat di lihat pada Tabel 3.

Tabel 3. Hasil Analisis LQ Subsektor Peternakan di Provinsi Lampung

\begin{tabular}{lr}
\multicolumn{1}{c}{$\begin{array}{c}\text { Lapangan Usaha Sektor } \\
\text { Pertanian }\end{array}$} & Nilai LQ \\
\hline a. Tanaman Pangan & 1,490298 \\
b. Tanaman Hortikultura & 0,424505 \\
c. Tanaman Perkebunan & 0,767396 \\
d. Peternakan & 1,232413 \\
e. Jasa Pertanian dan Perburuan & 1,480603 \\
f. Kehutanan & 0,236904 \\
g. Perikanan & 1,074479 \\
\hline
\end{tabular}

Berdasarkan data tabel di atas menunjukkan bahwa hasil LQ yang bernilai lebih dari 1 (satu) adalah subsektor tanaman pangan, peternakan, jasa pertanian dan perburuan, dan perikanan. Hal ini sejalan dengan pendapat Sitorus, dkk (2013) yang menunjukkan bahwa subsektor tanaman pangan merupakan subsektor unggulan di Provinsi Lampung. Berdasarkan Emalia (2018) menunjukkan bahwa subsektor peternakan memiliki nilai pengganda sebesar 2,01 bagi Provinsi Lampung.
Penentuan Nilai Shift Share (SS) Subsebktor Peternakan di Provinsi Lampung

$$
\text { Analisis Shift Share }
$$

dipergunakan sebagai alat analisis untuk mengidentifikasi keunggulan daerahnya serta menganalisis industri ataupun sektor yang menjadi dasar perekonomian daerah. Analisa SS digunakan untuk menganalisis pertumbuhan wilayah wilayah, dibandingkan dengan perkembangan ekonomi nasional (Nugroho dan Dahuri, 2012). Analisa SS juga menjadi alat untuk mengetahui peranan atau pergeseran suatu sektor di suatu daerah terhadap sektor nasional. Adapun hasil analisis SS di Provinsi Lampung seperti pada Tabel 4

\begin{tabular}{|c|c|c|}
\hline $\begin{array}{l}\text { Hasil Anali } \\
\text { Peternakan } \\
\text { Lampung }\end{array}$ & $\begin{array}{ll}\text { SS } & \text { S } \\
\text { di } & \end{array}$ & $\begin{array}{r}\text { Subsektor } \\
\text { Provinsi }\end{array}$ \\
\hline $\begin{array}{c}\text { Lapangan Usaha Sektor } \\
\text { Pertanian }\end{array}$ & $\begin{array}{c}\text { Nilai } \\
\text { SS }\end{array}$ & $\begin{array}{l}\text { Hasil } \\
\text { SS }\end{array}$ \\
\hline a. Tanaman Pangan & 0,06362 & $\begin{array}{l}\text { Positif } \\
\text { Negatif }\end{array}$ \\
\hline b. Tanaman Hortikultura & 0,11120 & Negatif \\
\hline c. Tanaman Perkebunan & $\begin{array}{r}0,00449 \\
-\end{array}$ & Negatif \\
\hline $\begin{array}{l}\text { d. Peternakan } \\
\text { e. Jasa Pertanian dan } \\
\text { Perburuan }\end{array}$ & $\begin{array}{l}0,02665 \\
0,02390\end{array}$ & Positif \\
\hline $\begin{array}{l}\text { f. Kehutanan dan } \\
\text { Penebangan Kayu }\end{array}$ & 0,36301 & Negatif \\
\hline g. Perikanan & 0,00973 & Positif \\
\hline
\end{tabular}

Hasil analisis SS terhadap 7 sektor pertanian di Provinsi Lampung menunjukkan hanya 3 subsektor yang bernilai positif yaitu subsektor tanaman 
pangan, subsektor jasa pertanian dan perburuan, dan subsektor perikanan. Hal ini sejalan dengan hasil penelitian yang dihasilkan oleh Sanudin, dkk (2015) yang menunjukkan bahwa subsektor kehutanan bukan merupakan subsektor unggulan di Provinsi Lampung.

\section{Penentuan Subsektor Unggulan pada Sektor Pertanian di Provinsi Lampung}

Tanaman pangan merupakan sektor unggulan yang telah lama berkembang di Provinsi Lampung. Hasil tanaman pangan ditanam untuk memenuhi kebutuhan masyarat sekitar Provinsi Lampung, karena bernilai cukup tinggi maka tanaman pangan di suplai ke daerah lainnya. Eliza. (2017) berpendapat bahwa pendekatan sektoral bertujuan mencapai tujuan pembangunan, sedangkan pendekatan regional lebih menitikberatkan pada wilayah mana yang perlu mendapat prioritas untuk dikembangkan, baru kemudian sektor apa yang sesuai untuk dikembangkan di masing-masing wilayah.

Setelah dihitung nilai LQ dan SS tahapan selanjutnya untuk menggolongkan sektor tersebut menggunakan metode Tipologi Klassen. Hasil analisis dengan menggunakan Tipologi Klassen yang membagi unggulan sektor menjadi empat kuadran, maka hasil dari pembagian kuadran tersebut terhadap subsektor-subsektor pertanian, seperti pada Gambar 3.

\begin{tabular}{|l|c|}
\hline $\begin{array}{c}\text { Kuadran II } \\
\text { Tidak ada }\end{array}$ & $\begin{array}{c}\text { Kuadran I } \\
\text { - Jasa Pertanian dan } \\
\text { Perkebunan } \\
\text { - Tanaman Pangan } \\
\text { - Perikanan }\end{array}$ \\
\hline Kuadran IV & Kuadran III \\
- Tanaman & - Peternakan \\
- Tortikultura & \\
- Tanaman & \\
Perkebunan & \\
Kehutanan dan & \\
\hline
\end{tabular}

Gambar 3. Hasil Analisis Tipologi Klasen pada Subsektor-subsektor Pertanian di Provinsi Lampung

Hasil analisis Tipologi Klassen tersebut terlihat bahwa sektor tanaman pangan, jasa pertanian dan perkebunan, serta perikanan tergolong kedalam kuadran I yakni sektor maju dan cepat tumbuh di Provinsi Lampung. Pada kuadran III ditempati oleh sektor peternakan sebagai sektor yang berkembang cepat. Adapun subsektor yang menempati kuadran IV yaitu sektor relatif tertinggal adalah (1) tanaman perkebunan, (2) Kehutanan dan Kayu, (3) Tanaman Holtikultura. Dengan demikian bahwa subsektor-subsektor unggulan pada sektor pertanian di Provinsi Lampung adalah tanaman pangan, jasa pertanian dan perburuan, dan perikanan. Sedangkan susbektor peternakan bukan sebagai subsektor unggulan di Provinsi 
Lampung. Hasil penelitian ini dapat memberikan informasi penting bagi Pemerintah Daerah Provinsi Lampung terhadap subsektor-subsektor pertanian yang memiliki keunggulan. Berdasarkan Suparnoko (2010), potensi ekonomi daerah adalah kemampuan ekonomi yang ada didaerah yang dapat dikembangkan menjadi sumber penghidupan rakyat setempat dan dapat mendorong perekonomian daerah secara keseluruhan untuk berkembang dengan sendirinya dan berkesinambungan.

\section{KESIMPULAN}

Berdasarkan hasil pembahasan sebelumnya dapat disimpulkan bahwa subsektor tanaman pangan, peternakan, jasa pertanian dan perburuan, dan perikanan memiliki nilai $\mathrm{LQ}>1$. kan merupakan subsektor pertanian yang berkontribusi besar pada PDRB Provinsi Lampung. Adapun yang memiliki nilai Shift Share (SS) positif adalah subsektor tanaman pangan, jasa pertanian dan perburuan, dan perikanan. Berdasarkan kedua analisis LQ dan SS dapat dihitung nilai Tipologi Klasen yang menunjukkan subsektor-subsektor pertanian yang memiliki unggulan adalah subsektor tanaman pangan, jasa pertanian dan perburuan, dan perikanan. Subsektor peternakan bukan sebagai unggulan dari Provinsi Lampung.

\section{DAFTAR PUSTAKA}

Aulia, A.R., \& Yulianti, A.L., (2019) Pegaruh City Branding " $A$ Land $O f$ Harmony" Terhadap Minta Berkunjung ke Puncak, Kabupaten Bogor. Jurnal Ilmiah Manajemen, Ekonomi, dan Akuntansi, 3,(3), 6775.

Badan Pusat Statistik (BPS). (2019) Direktori Perusahaan Peternakan Provinsi Lampung 2019. Lampung: Badan Pusat Statistik Provinsi Lampug.

Badan Pusat Statistik (BPS)., (2020) Peternakan dalam Angka 2020. Jakarta: Badan Pusat Statistik Republik Indonesia (BPS-RI).

Badan Pusat Statistik (BPS)., (2021) Provinsi Lampung dalam Angka 2021. Lampung: Badan Pusat Statistik Provinsi Lampug.

Eliza. (2017) Kontribusi Sektor Trasportasi Terhadap Perekonomian Daerah di Provinsi Sumatera Barat. Jurnal Plano Madani. 6(2), 177-184.

Emilia, Z. (2018). Telaah Sektor Pertanian dalam Perekonomian Provinsi Lampung: Sebuah Eksplorasi dengan Data Input Output. Jurnal Ekonomi Pembangunan, Vol. 7 (1): 57-74.

Firman, A., \& Obed H.N., (2020) Penentuan Wilayah-Wilayah Sentra Pengembangan Ternak Kecil Di Provinsi Nusa Tenggara Timur. Jurnal Ilmu-ilmu Sosial dan Humaniora, 22,(1), 64-71.

Goschin, Z. (2014). Regional growth in Romania after its accession to EU: a shiftshare analysis approach. Emerging Markets Queries in Finance and Business. Procedia 
Economics and Finance. 15: 169 175.

Guimaraes, P., O. Figueiredo, \& D. Woodward. (2009). Dartboard tests for the location quotient. Regional Science and Urban Economics. 39: 360-364.

Jhingan, M.L. (2008). Ekonomi Pembangunan dan Perencanaan. Jakarta: PT Raja Grafindo Persada.

Mahroji, D.,\& Indrawati, M. (2019) Analisis Sektor Unggulan Dan Spesialisasi Regional Kota Bandar Lampung. Jurnal Ekonomi, Bisnis dan Manajemen. 9(1), 1-8.

Muta'ali, L., (2015) Teknik Analisis Regional. Yogyakarta: Badan Penerbit Fakultas Geografi (BPFG)

Nugroho, Iwan \& Rokhmin Dahuri (2012). Pembangunan Wilayah: Perspektif Ekonomi, Sosial, dan Lingkungan. Jakarta: LP3ES

Riadi, D.M.M. (2000). Pembangunan Daerah Melalui Pengembangan Wilayah. Disampaikan pada Acara Diseminasi dan Diskusi ProgramProgram Pengembangan Wilayah dan Pengembangan Ekonomi Masyarakat di Daerah, Bogor, 1516 Mei 2000.

Rice, P. F. \& M. J. Harton. (2010). Analysis of Recent Changes in Arkansas Personal Income 20072009: A Shift Share Approach. Journal of Business Administration Online, 9(2):1-12.

Sapriadi \& Hasbullah. (2015) Analisis Penentuan Sektor Unggulan Perekonomian Kabupaten Bulukumba. Jurnal Iqtisaduna, 1, (1), 71-86.
Sanudin, S.A. Awang, R. Sadono, \& R.H Purwanto. (2015). Kontribusi Sektor Kehutanan Terhadap Perekonomian Wilayah di Provinsi Lampung. Jurnal Bumi Lestari, Vol. 15 (1): 10-19.

Sirojuzilam. (2007). Analisis Ketimpangan Ekonomi Wilayah Barat dan Wilayah Timur Propinsi Sumatera Utara dan Kaitannya Dengan Perencanaan Wilayah. Sekolah Pascasarjana Universitas Sumatera Utara.

Sitorus, S.R.P., B.W Widodo, \& D.R Panuju. (2013). Identifikasi Komoditas Basis Tanaman Pangan dan Arahan Pengembangannya di Provinsi Lampung. Jurnal Tanah Lingkungan, Vol. 15 (1): 29-38.

Sjafrizal, (1997) Pertumbuhan Ekonomi dan Ketimpangan Regional Wilayah Indonesia Bagian Barat. Majalah Ekonomi Prisma LP3ES, 26,(3), 27-38.

Suparmoko, M. (2010), Ekonomi Publik: untuk Keuangan dan Pembangunan Daerah, Edisi Pertama, Yogyakarta: Andy.

Widjaya, D.S.M. (2012) Analisis Penentuan Sektor Unggulan Perekonomian Wilayah Kabupaten Ngawi. Tesis Program Pascasarjana Ekonomi dan Studi Pembangunan, Fakultas Ekonomi, Universitas Sebelas Maret, Surakarta.

Yuuhaa, M.I.W., Cahyono, H., (2013) Analisis Penentuan Sektor Basis dan Sektor Potensial di Kabupaten Lamongan. Jurnal Pendidikan Ekonomi, 1,(3), 1-15. 